\title{
\#16
}

\section{Kekerasan Terhadap Jurnalis: Tantangan Bagi Media dan Demokrasi}

\author{
Eni Maryani
}

Wacana tentang kekerasan terhadap jurnalis menyadarkan kita bahwa dibalik berita-berita penting yang kita baca, lihat atau dengar terdapat aktor-aktor yang memiliki resiko untuk mewujudkannya. Merujuk pada pemikiran Kant, kerja jurnalis adalah sebuah profesi yang berkaitan dengan upaya memeriksa beragam pengetahuan yang akan dihadirkan ke masyarakat umum. Pengetahuan bukan sesuatu yang diperoleh secara dogmatis tapi melalui pencarian dan proses kritisisme yang didasarkan pada akal budi manusia (Hardiman, 2011; Kant, 2021).

Berbeda dengan peneliti yang hasil kerjanya akan berputar di kelompok elit berpendidikan, maka kerja jurnalis harus 
menghadirkan pengetahuan itu untuk masyarakat umum. Merujuk pada publiknya, maka kerja jurnalis akan memiliki resiko yang lebih besar karena pengetahuan yang dihadirkannya akan menerpa lebih banyak orang sehingga mampu berfungsi sebagai kontrol sosial. Itulah sebabnya, banyak pemilik kuasa menganggap jurnalis adalah sosok yang membahayakan terutama mereka yang bersifat otoriter dan ingin terus mempertahankan kekuasaannya.

Hal-hal terkait dengan kerja jurnalis dalam menghadirkan pengetahuan juga menarik, dan penting dipahami. Bagi Kant hal penting dari berkembangnya sebuah pengetahuan bukan pada pengetahuan itu saja akan tetapi pada proses atau cara memperoleh pengetahuan (Irfan, 2010; Kant, 2021). Jika para peneliti berpegang pada metode riset yang digunakan maka para jurnalis menjunjung apa yang mereka sebut sebagai prinsip-prinsip Jurnalis dan Kode Etik Jurnalistik (Kovach \& Tom, 2001). Para jurnalis tidak dapat sepenuhnya mengklaim hasil kerja mereka atau pemberitaan media bersifat objektif, akan tetapi prosedur atau cara kerja seorang jurnalis harus diakui bersifat objektif, sesuai dengan kaidah atau prinsip yang dikandungnya. Cara kerja jurnalis terikat dan harus memenuhi tuntutan dalam aturan yang ditetapkan sebagai kaidah-kaidah jurnalistik. Paling tidak terdapat sembilan elemen penting dalam kaidah jurnalistik yaitu, 1) kebenaran, 2) loyalitas pada publik 3) disiplin verifikasi, 4) independen dari yang diliput, 5) pemantau kekuasaan, 6) penyedia forum publik, 7) mampu memproduksi sesuatu yang menarik dan relevan, 8) komprehensif dan proporsional, serta 9) wajib mengikuti nurani mereka (Kovach \& Tom, 2001). Jika jurnalis tidak menjalankan elemen penting tersebut dalam kerjanya, maka dapat dikatakan bahwa kerja jurnalis tersebut belum profesional.

Berdasarkan pemahaman di atas maka kerja jurnalistik menjadi kerja yang membutuhkan proses penyelidikan untuk menghasilkan atau memfasilitasi terungkapnya pengetahuan yang memenuhi kaidah-kaidah jurnalistik sehingga dapat dipertangungjawabkan. 
Agar dapat memenuhi tuntutan tersebut, maka seorang jurnalis harus bekerja keras dan bersikap kritis. Untuk itu proses investigasi menjadi salah satu proses yang penting dalam kerja jurnalis ketika melaporkan sebuah peristiwa dan segala hal yang ada di balik peristiwa tersebut (Kurnia, 2004).

Pengetahuan yang disebarkan Jurnalis melalui institusi media ke masyarakat menjadi syarat terciptanya opini publik. Beragam opini publik yang terbangun tentang kepentingan publik menjadi aspek kontrol yang penting dalam negara yang demokratis. Opini publik juga salah satu bentuk partisipasi masyarakat yang dapat mewujudkan pemerintahan atau negara yang demokratis.

Merujuk pada penjelasan di atas maka bahasan tentang terjadinya kekerasan terhadap jurnalis menjadi ancaman bagi media dan demokrasi menjadi amat relevan dan penting. Upaya melawan atau meminimalkan kekerasan terhadap jurnalis harus terus diwacanakan sehingga menjadi sesuatu yang penting untuk disadari. Masyarakat pelu mengetahui begaimana implikasi kekerasan terhadap jurnalis pada kehidupan bermasyarakat atau bernegara. Bagaimana kerugian yang diakibatkan oleh kekerasan terhadap jurnalis bagi masyarakat, terutama bagi kelangsungan sitem demokrasi yang telah kita pilih dan sepakati.

\section{Liputan Media dan Demokratisasi}

Secara konseptual ketika berbicara tentang demokrasi maka kita bicara tentang sebuah sistem yang menjadikan rakyat sebagai subjek dalam pengelolaan negara. Secara ideal sistem ini menjalani sebuah pengelolaan negara yang dilakukan oleh rakyat dan untuk rakyat. Indonesia berada dalam proses membangun dan menciptakan sistem komunikasi dan informasi yang demokratis (Siregar, 2019). Oleh karena itu keterlibatan rakyat dalam penyelenggaraan negara menjadi penting. Permasalahannya adalah bagaimana rakyat memahami berbagai hal yang terjadi 
terkait dengan negara, yaitu segala hal yang berkaitan dengan kepentingan publik?

Melalui liputan medialah umumnya masyarakat dapat mengetahui bagaimana para wakilnya di legislatif atau eksekutif bekerja, dan apa serta bagaimana hasil kerja mereka. Oleh karena itu, dalam konteks sistem demokrasi, media menjadi pilar keempat setelah pilar legislatif, eksekutif dan yudikatif. Bondan Winarno salah seorang tokoh jurnalis Indonesia, menyatakan bahwa seorang jurnalis harus mampu menggali cerita di balik berita, menyajikan analisis berita, dan menempatkan informasi pada konteksnya, agar pembaca memahami big picture dari peristiwa yang sedang terjadi (putting all the informatin in the right context). Jurnalis juga harus mampu mengisi berbagai celah dari peristiwa (filling in the gaps) untuk menggelar kejelasan bagi pembacanya (Kurnia, 2004).

Akan tetapi selain kemampuan jurnalis, hasil kerja jurnalis atau pers sangat tergantung pada sistem sosial politik yang berlaku, dan bagaimana sebuah bangsa ingin mengawasi sikap dan perilaku orang serta berbagai lembaga sosial yang ada. Selain itu, sistem kerja pers juga sangat terkait dengan perkembangan media yang ada (Kurnia, 2004). Sementara itu untuk merealisasikan fungsi sosialnya pers juga kadangkala mengalami kesulitan.

Masih dibutuhkan berbagai upaya jurnalis untuk menjalankan fungsi sosial media di dalam masyarakat. Sementara fungsi sosial media atau pers dibutuhkan untuk meningkatkan peran media yang memiliki interplay relation dengan pekembangan komunikasi yang demokratis (Maryani, 2021). Komunikasi yang demokratis juga hanya dapat terjadi jika ada partisipasi masyarakat yang melahirkan opini publik. Peran pers membangun opini publik dalam model demokrasi deliberatif menjadi dasar terjadinya kontrol terhadap demokrasi dapat direalisasikan (Hardiman \& Priotomo, 2009). Selain itu, pers juga berperan melahirkan keragaman perspektif terhadap beragam isu di masyarakat. Sebuah riset di Amerika 
menegaskan bahwa hal tersebut dapat terjadi jika Jurnalis tidak hanya mengandalkan narasumber dari kelompok elit, akan tetapi terbiasa mencari sumber informasi alternatif dan memberi lebih banyak individu kesempatan untuk berbicara (Wolfgang et al., 2021).

Indonesia telah melewati sebuah reformasi yang cukup penting untuk memperjuangkan sistem demokrasi yang selama 30 tahun dimanipulasi dalam kerangka 'demokrasi pancasila'. Akan tetapi dalam proses merealisasikan demokrasi yang dicita-citakan, tidak dapat terjadi hanya dengan menurunkan seorang pemimpin yang otoriter. Indonesia harus memiliki sistem yang dapat mengkonsolidasikan demokrasi dalam perjalanannya. Peran pers dalam sistem tersebut menjadi sangat penting

Berkaitan dengan konsolidasi demokrasi, diyakini bahwa media yang bebas dan kompetitif dapat berfungsi sebagai alat yang dapat digunakan untuk memecah kolusi elit. Secara spesifik, misalnya pemberitaan skandal para pejabat publik yang secara rutin diangkat media dapat mendorong dan mempromosikan transparansi. Selain itu, demokrasi juga dapat berfungsi dengan terjadinya pergantian elit secara regular. Merujuk pada pemahaman di atas, maka kita bisa memahami bagaimana sebuah transisi demokrasi dapat berhasil dan yang lainnya gagal, atau hanya melahirkan keadaan pseudodemokrasi yang kronis (McCoy, 2019).

Kondisi pseudodemokrasi inilah yang dikhawatirkan terjadi di Indonesia, jika media atau pers dan jurnalis sebagai aktornya tidak dapat menjalankan peran dan fungsinya di negeri ini. Sesuai dengan kesepakatan yang dicantumkan dalam Pasal 3 ayat 1, UU No 40 th 1999 tentang pers, ditetapkan bahwa pers nasional berfungsi sebagai media informasi, pendidikan, hiburan, dan kontrol sosial. Dengan kata lain kesepakatan itu menegaskan bahwa jurnalis 
dengan fungsi kontrol sosial yang dimiikinya merupakan hal penting dalam mewujudkan demokratisasi.

\section{Fakta dan Penanganan Kekerasan Terhadap Jurnalis}

Berdasarkan catatan Aliansi Jurnalis Independen (AJI), selama 2016 , tercatat beberapa data kekerasan terhadap jurnalis. Terdapat 78 kasus kekerasan dan satu satunya merupakan pembunuhan. Kategori pelaku kekerasan tertinggi dilakukan oleh warga dengan 26 kasus, diikuti oleh polisi 13 kasus, pejabat pemerintah (eksekutif) 7 kasus, dan TNI, orang tidak dikenal, aparat pemerintah daerah (Satpol PP) masing-masing 6 kasus.

Kekerasan fisik merupakan kasus terbanyak (35), disusul pengusiran atau pelarangan liputan yaitu 17 kasus, Ancaman kekerasan atau teror (9 kasus), dan perusakan alat atau data hasil liputan ada 7 kasus. Untuk kategorisasi wilayah, Jakarta Pusat dan Medan menempati posisi tertinggi, terjadinya kasus kekerasan terhadap jurnalis yaitu 7 kasus. Sementara Makasar 4 Kasus, dan Bandung serta Bandar Lampung, 3 kasus.

Lemahnya penegakan hukum terkait kasus kekerasan terhadap jurnalis menyebabkan terjadinya kekerasan yang berulang. Pada tahun 2016 terdapat 78 kasus termasuk yang belum diproses hukum, yaitu kekerasan yang dilakukan aparat penegak hukum baik dilakukan oleh TNI, polisi, satpol PP atau aparat pemerintah. Merujuk pada kondisi tersebut, maka kita harus dapat mendorong penegakan hukum yang lebih baik. Ironisnya selama 2015-2016, polisi menjadi pelaku kekerasan terbanyak kedua, setelah warga, sehingga polisi sebagai penegak hukum justru terkesan menjadi musuh kebebasan pers.

Jika dilihat data kekerasan lima tahun terakhir (2017-2021), kondisi tersebut belum banyak berubah. AJI mencatat kekerasan terhadap 
jurnalis terus terjadi dan dalam 5 tahun terakhir mencapai 315 kasus. Tahun 2020 merupakan tahun yang memiliki catatan kekerasan terhadap Jurnalis paling tinggi yaitu 84 kasus, dan sebagain besar terjadi pada bulan Oktober (57 kasus). Tingginya kasus kekerasan di bulan Oktober 2020 sangat berkaitan dengan situasi politik di Indonesia. Pada bulan Oktober terjadi demonstrasi penolakan terhadap Omnibus Law UU Cipta Kerja di 9 kota dan sebagian besar di Pulau Jawa. Menurut berita, tercatat demonstrasi yang terjadi secara beruntun dan hampir bersamaan di berbagai kota yaitu Bandung dan Banten (6/10), Semarang dan Bekasi (7/10), Jakarta, Surabaya, Malang, Yogyakarta, dan Makasar $(8 / 10)$ dan semua berakhir ricuh (Shalihah, 2020).

Merujuk data di atas maka kekerasan terhadap jurnalis memiliki keterkaitan dengan situasi politik yang memicu terjadinya konflik di masyarakat. Dalam situasi seperti itu maka keberadaan jurnalis sangat penting, akan tetapi sekaligus memiliki resiko bahaya bagi mereka. Ketika situasi politik menurun atau dapat diredam, maka terlihat data kekerasan di tahun berikutnya (2021) mengalami penurunan yag cukup signifikan yaitu hampir $50 \%$ sehingga kasus kekerasan terjadap Jurnalis yang terjadi hanya 43 kasus. Tahun 2021 beragam isu tentang Pandemi-Corona mengalahkan isu-isu politik, termasuk berbagai kebijakan pemerintah yang kontroversial dan memicu konflik.

Tabel 1. Data AJI tentang Kasus Kekerasan Terhadap Jurnalis

\begin{tabular}{clcccccc}
\hline No & Bln/Thn & $\mathbf{2 0 1 7}$ & $\mathbf{2 0 1 8}$ & $\mathbf{2 0 1 9}$ & $\mathbf{2 0 2 0}$ & $\mathbf{2 0 2 1}$ & Jml \\
\hline $\mathbf{1}$ & Januari & 2 & 6 & 5 & 2 & - & \\
\hline $\mathbf{2}$ & Februari & 11 & 13 & 2 & 1 & 1 & \\
\hline $\mathbf{3}$ & Maret & 6 & 8 & 3 & 3 & 4 & \\
\hline $\mathbf{4}$ & April & 5 & 5 & 1 & 2 & 2 & \\
\hline $\mathbf{5}$ & Mei & 10 & 6 & 12 & 2 & 4 & \\
\hline $\mathbf{6}$ & Juni & 3 & 4 & - & 2 & 9 & \\
\hline
\end{tabular}




\begin{tabular}{clcccccc}
\hline $\mathbf{7}$ & Juli & 2 & 3 & 1 & 2 & 2 & \\
\hline $\mathbf{8}$ & Agustus & 3 & 4 & 2 & 6 & 2 & \\
\hline $\mathbf{9}$ & September & 5 & 1 & 13 & 5 & 4 & \\
\hline $\mathbf{1 0}$ & Oktober & 9 & 2 & 9 & 57 & 7 & \\
\hline $\mathbf{1 1}$ & November & 5 & 8 & 2 & 2 & 6 & \\
\hline $\mathbf{1 2}$ & Desember & 5 & 4 & 8 & - & 2 & \\
\hline & Jumlah & $\mathbf{6 6}$ & $\mathbf{6 4}$ & $\mathbf{5 8}$ & $\mathbf{8 4}$ & $\mathbf{4 3}$ & \multirow{2}{*}{$\mathbf{3 1 5}$} \\
\hline
\end{tabular}

Sumber: (Aliansi Jurnalis Independen, 2022)

AJl selain mencatat jumlah kekerasan pertahun dan jumlahnya di masing-masing bulan dalam setiap tahunnya seperti terlihat di Tabel 1, AJi juga mencatat kekerasan terhadap jurnalis berbasis pada sebaran wilayahnya. Tahun 2017 berdasarkan laporan AJI, korban kekerasan terhadap jurnalis terjadi di 47 kota/kabupaten di Indonesia, dan tahun 2018 terjadi di 50 kota/kabupaten. Selanjutnya di tahun 2019 kasus kekerasan terhadap jurnalis terjadi di 23 wilayah kota/kabupaten, dan tahun 2020 serta 2021 terjadi di 25 wilayah kota/kabupaten serta 31 wilayah kota/kabupaten.

Kota/Kabupaten tempat terjadinya kekerasan terhadap jurnalis tersebar di berbagai wilayah Indonesia, baik di kota-kota besar maupun di kabupaten-kabupaten kecil. Selain itu kekerasan terhadap jurnalis juga terjadi di berbagai pulau-pulau besar di Indonesia, yaitu; di Pulau Jawa, Nusa Tenggara, Bali, Sumatera, Kalimantan, Sulawesi, Maluku, dan Papua. Data tersebut menunjukan bahwa kerja jurnalis di wilayah manapun di Indonesia mengandung resiko menjadi korban tindak kekerasan. Terkait jenis kekerasan yang menimpa para jurnalis, AJI mencatat beberapa jenis kekerasan dan jumlah masing-masing jenis kekerasan tersebut pertahun.

Kategorisasi jenis-jenis kekerasan terhadap jurnalis secara garis besar juga dapat digolongkan paling tidak ke dalam tiga kategori yaitu kekerasan sebelum liputan dilakukan, saat liputan dan 
setelah liputan dipublikasikan. Selain itu pihak yang melakukan kekerasan dapat berasal dari luar lembaga media atau dapat juga dari dalam Lembaga, misalnya ketika pemilik tidak berkenan dan melarang jurnalis di medianya memuat pemberitaan terhadap sebuah kasus.

Berdasarkan jenis kekerasan terhadap jurnalis dilihat dari tindak kekerasan yang dialami seperti dicatat AJI, dapat dikategorikan ke dalam 12 kategori seperti terlihat dalat tabel 2.

Tabel 2. Data AJI tentang Kasus Kekerasan Terhadap Jurnalis Berdasarkan Jenis Tindak Kekerasan

\begin{tabular}{|c|c|c|c|c|c|c|c|}
\hline No & Jenis Kekarasan & 2017 & 2018 & 2019 & 2020 & 2021 & Jml \\
\hline 1. & Ancaman & & & & 1 & 7 & \\
\hline 2. & $\begin{array}{l}\text { Ancaman } \\
\text { dengan } \\
\text { Kekerasan/Teror }\end{array}$ & 7 & 10 & 6 & 11 & 9 & \\
\hline 3. & Kekerasan Fisik & 34 & 16 & 22 & 15 & 7 & \\
\hline 4. & $\begin{array}{l}\text { Mobilisasi } \\
\text { Massa/ } \\
\text { Penyerangan } \\
\text { Kantor Redaksi }\end{array}$ & 1 & 2 & - & 1 & & \\
\hline 5. & $\begin{array}{l}\text { Pengusiran/ } \\
\text { Larangan } \\
\text { Liputan }\end{array}$ & 13 & 11 & 5 & 3 & 7 & \\
\hline 6. & $\begin{array}{l}\text { Perusakan Alat/ } \\
\text { Hasil liputan }\end{array}$ & 6 & 9 & 14 & 20 & & \\
\hline 7. & $\begin{array}{l}\text { Intimidasi Lisan } \\
\text { oleh Pejabat } \\
\text { Publik }\end{array}$ & & 5 & 1 & 18 & & \\
\hline 8. & $\begin{array}{l}\text { Penghapusan } \\
\text { Hasil Liputan }\end{array}$ & & & & 5 & 3 & \\
\hline 9. & Penahanan & & & & 2 & 1 & \\
\hline 10. & $\begin{array}{l}\text { Penuntutan } \\
\text { Hukum (Pidana } \\
\text { dan Perdata) }\end{array}$ & 5 & 7 & 7 & 6 & 4 & \\
\hline
\end{tabular}




\begin{tabular}{|c|c|c|c|c|c|c|c|}
\hline 11. & Serangan Digital & & & & & 5 & \\
\hline 12. & $\begin{array}{l}\text { Sensor/Pelarang } \\
\text { an Pemberitaan }\end{array}$ & & 4 & 3 & 2 & & \\
\hline & Jumlah & 66 & 64 & 58 & 84 & 43 & 315 \\
\hline
\end{tabular}

Sumber: (Aliansi Jurnalis Independen, 2022)

Terkait wilayah yang seringkali memiliki jumlah kekerasan terhadap Jurnalis tertinggi di setiap tahun dibanding daerah lainnya adalah Kota Jakarta Pusat yaitu tertinggi di tahun 2019 (17 kasus) dan Kota Malang di tahun 2020 (15 kasus) dan terakhir kasus tertingggi di tahun 2020 terjadi di Kota Surabaya (10 kasus). Sementara jurnalis Indonesia yang yang tewas karena pemberitaan yang dibuatnya, sejarah mencatat Muhammad Fuad Syahfrudin alias Udin (Bernas-Yogyakarta; 1996), Naimullah (Sinar Pagi-Kalimantan Barat; 1997), Agus Mulyawan (Asia Press; 1999), Muhammad Jamaludin (TVRI; 2003), Ersa Siregar (RCTI; 2003), Herliyanto (Delta Pos; 2006), Adriansyah Matra'is Wibisono (TV Lokal-Merauke; 2010), dan Alfred Mirulewan (Pelangi-Maluku; 2010).

Kekerasan terhadap Jurnalis yang terjadi karena tekanan internal dari pemilik institusi media, umumnya terjadi ketika pemilik menjadikan institusi medianya sebagai institusi ekonomi atau alat kepentingan politiknya. Di dalam catatan AJI terdapat kekerasan yang dilakukan dalam bentuk sensor atau larangan pemberitaan. Hal tersebut terbukti dalam riset terhadap media di Indonesia, yang menyimpulkan bahwa praktik self-censorship dan vested interest pemilik media tampak dalam agenda-setting media, dan mengancam eksistensi ruang publik yang terbuka (Nugroho et al., 2013).

Walaupun tidak banyak diwacanakan secara resmi, salah seorang jurnalis mengungkapkan bahwa kekerasan dari pihak internal media terjadi pada beberapa jurnalis yang mengalami pemecatan bukan karena masalah profesionalisme mereka. Terdapat kasus 
pemecatan karena jurnalis memperjuangkan serikat pekerja di perusahaannya, melakukan investigasi yang tidak sesuai dengan keinginan, atau dianggap tidak dapat sejalan dengan kepentingan pemilik, atau dikorbankan untuk menyelamatkan kepentingan pemilik media.

Selain itu kekerasan pada jurnalis yang jarang diwacanakan juga terjadi dalam bentuk-bentuk kasus yang lebih spesifik, atau personal. Kekerasan tersebut biasanya terjadi pada jurnalis perempuan, minoritas seksual, dan etnis minoritas, yang dapat berbentuk marginalisasi pekerjaan, pembungkaman di tempat kerja, atau kondisi kerja yang eksploitatif (Brambila \& Hughes, 2019).

Siapa yang membela dan mempertanyakan perlakuan tidak adil terhadap para jurnalis yang mengalami tindak kekerasan? Sebagian kasus seolah-olah menjadi masalah pribadi para jurnalis, yang kemudian diselesaikannya sendiri. Padahal kasus-kasus tersebut merupakan tindak kekerasan yang membuat jurnalis terancam dalam upaya mereka untuk menjalankan fungsi pers yang informatif dan sebagai kontrol sosial.

Adanya ketetapan yang tercantum dalam UU no 40 th 1999 Pasal 3 ayat (2) yang menyatakan bahwa disamping berfungsi sebagai media informasi, pendidikan, hiburan, dan kontrol sosial, nasional juga dapat berfungsi sebagai lembaga ekonomi menjadi celah bagi para pengusaha. Saat ini fungsi pers atau media sebagai lembaga ekonomi menjadi lebih dominan (Nugroho et al., 2013). Fungsi media untuk memberi hiburan dan untuk mencari keuntungan sangat dominan dibanding fungsi informasi, pendidikan dan kontrol sosial, terutama di media penyiaran televisi. Sementara itu, media penyiaran mainstream seperti televisi justru merupakan media yang penetrasinya paling tinggi di masyarakat. Media online yang lebih banyak diminati generasi milenial juga tidak terlepas dari orientasi 
ekonomi sehingga meminimalkan fungsi media terutama dalam hal informasi dan kontrol sosial. Bahkan sebagian besar konten hiburan di media penyiaran seringkali bertentangan dengan nilainilai dalam pendidikan.

Masih lemahnya penanganan tindak kekerasan terhadap Jurnalis di Indonesia, mengindikasikan kebebasan pers dan berekspresi di Indonesia masih memiliki tantangan yang cukup serius. Walaupun tahun 2017 Indonesia menjadi tuan rumah World Press Freedom Day (WPFD), akan tetapi data World Press Freedom Index 2021 masih menempatkan Indonesia di rangking 113 dari 180 negara. Rangking indeks kebebasan pers itupun belum mengalami perbaikan sampai tahun 2020 yaitu ada di urutan 119 (Reporter Without Borders, 2021).

Data tersebut sejalan dengan masih rendahnya upaya untuk menyelesaikan kasus-kasus kekerasan pada jurnalis, bahkan yang menewaskan jurnalis. Salah seorang narasumber dari Dewan Pers dalam sebuah perbincangan bahkan mengemukakan bahwa terdapat beberapa kasus kekerasan pada jurnalis yang kasusnya dinyatakan bersifat personal, artinya dianggap tidak terkait dengan pekerjaaan. Hal ini tentu saja bukan hal yang tidak mungkin, akan tetapi diperlukan sebuah investigasi yang cukup mendalam untuk menetapkan, atau memastikan bahwa kekerasan yang menimpa seorang jurnalis tidak terkait dengan pekerjaannya.

Perkembangan dunia digital juga melahirkan Undang-undang baru yang beberapa pasalnya dianggap memiliki peluang disalahgunakan untuk melemahkan kebebasan pers, dan kebebasan berekspresi di Indonesia. Beberapa Undang-undang baru itu diantaranya Undang-undang Internet dan Transaksi Elektronik, Undang-undang Intelijen Negara, dan Undang-undang Pornografi (Safenet, 2019). 
Laporan SafeNet juga mengungkapkan bahwa keberadaan UU ITE punya potensi mengancam kebebasan aktivitas di dunia internet. Selain itu juga dapat memunculkan konflik-konlfik baru, seperti saat pemerintah memblokir situs internet tanpa pemberitahuan. Kasus ini salah satunya menimpa situs media SuaraPapua.com yang mengalami pemblokiran oleh Kemenkominfo tanpa mendapat peringatan sebelumnya. Banyak pihak mengkhawatirkan kasus serupa akan terulang, sehingga menghambat kerja jurnalis dalam melakukan pemberitaan.

Berdasarkan berbagai paparan di atas maka dapat dipahami bahwa terhambatnya kerja jurnalis akan memengaruhi pers dalam melaksanakan peranan seperti yang tercantum dalam pasal $6 \mathrm{UU}$ no 40 th 1999. Pasal tersebut secara umum mencakup isu tentang pemenuhan hak masyarakat akan informasi; penegakkan demokrasi, supremasi hukum, dan Hak Asasi Manusia, mendukung kebhinekaan; menghasilkan pendapat umum dengan informasi yang tepat, akurat, dan benar.

Apabila peran-peran tersebut tidak terwujud, maka peran pers untuk melakukan pengawasan, kritik, koreksi, dan saran terkait kepentingan publik serta memperjuangkan keadilan dan kebenaran tidak akan terwujud. Sementara itu selalu ada pihak-pihak yang terfokus pada kepentingan dirinya dan kelompoknya yang tidak sejalan dengan prinsip demokrasi. Oleh karena itu tantangan dari pihak-pihak yang berusaha menghambat kerja jurnalis bahkan mengancam jurnalis akan selalu ada.

Terkait tantangan tersebut maka Pasal 8 UU No 40 th 1999 tentang Pers mencantumkan bahwa dalam melaksanakan profesinya, wartawan mendapat perlindungan hukum. Merujuk pada pasal tersebut maka beberapa pertanyaan muncul terkait dengan implementasinya. Terkait perlindungan hukum bagi jurnalis, maka pertanyaanya adalah seperti apa dan siapa atau lembaga apa yang 
memastikan perlindungan hukum bagi jurnalis telah diberikan atau dijamin.

\section{Keselamatan Jurnalis, Liputan Media, dan Demokrasi}

Ketiga hal penting yang dicatat sebagai sub judul di atas, yaitu terkait keselamatan jurnalis, liputan media, dan demokrasi adalah rangkaian aspek yang satu sama lainnya terkait. Sebuah negara yang mendeklarasikan menganut sistem demokrasi, seharusnya dapat menjamin warganya memiliki kebebasan berbicara atau berpendapat. Selain itu, tolok ukur penting terkait hal itu adalah kebebasan para jurnalis untuk bekerja atau menyuarakan pemikiran maupun kritik masyarakat melalui medianya. Media harus bersifat bebas dan kompetitif dalam menjalankan fungsinya tersebut.

Selain itu, media yang bebas dan kompetitif dapat berfungsi sebagai alat yang dapat digunakan untuk memecah kolusi elit sebagai bentuk konsolidasi demokrasi. Sebagai contoh, pemberitaan skandal para pejabat publik yang secara rutin diangkat media akan mendorong dan mempromosikan transparansi, selain itu demokrasi juga dapat berlanjut jika terjadi pergantian elit secara regular. Merujuk pada pemahaman di atas maka dapat dipahami bahwa sebuah transisi demokrasi dapat berhasil, dan yang lainnya gagal atau hanya melahirkan keadaan pseudodemokrasi yang kronis (McCoy, 2019).

Oleh karena itu untuk mewujudkan demokrasi, jaminan atau perlindungan keamanan terhadap kerja-kerja jurnalis menjadi sangat penting. Artinya jika para jurnalis mengaku bahwa keselamatan dirinya terancam, atau tidak terlindungi maka kita perlu bertanya mungkinkah peran jurnalis mendukung demokrasi dapat berjalan dengan seharusnya? Ketika jurnalis merasakan keselamatan mereka tidak terjamin, atau perlindungan bagi keselamatan mereka rendah, maka hal pertama yang akan 
dipengaruhi adalah kualitas kerjanya, atau hasil liputan mereka yang kemudian tayang atau dimuat di media.

Di akhir tahun 2020, dalam sebuah pertemuan dengan para jurnalis di Kabupaten Pangandaran, Jawa Barat terungkap beberapa kasus kekerasan terhadap jurnalis yang dilakukan para preman yang tidak jelas kepentingannya. Para jurnalis menyatakan bahwa kekerasan yang mereka alami, diyakini berkaitan dengan liputan berita yang mereka lakukan. Pengalaman tersebut diakui jurnalis yang mengalami kekerasan terkait dengan liputan yang dibuatnya.

Tindak kekerasan yang dialami seorang jurnalis, diakui memengaruhi keberaniannya untuk melakukan liputan atau investigasi lebih lanjut, terkait kasus yang terjadi di daerahnya. Jurnalis tersebut mengaku bahwa dia tidak berani mengambil resiko untuk terus meliput kasus tersebut. Keputusan tersebut diambil karena kurangnya jaminan keselamatan atau perlindungan terhadap dirinya baik dari aparat, maupun dari media tempatnya bekerja.

Merujuk kasus tersebut, maka keselamatan jurnalis di daerah baik yang meliput untuk media lokal jaringan, maupun media lokal setempat tidak bisa diabaikan. Salah seorang warga di tempat yang sama mengatakan bahwa daerah mereka terus dikembangkan sebagai daerah wisata akan tetapi tidak bisa melepaskan diri dari keberadaan preman. Keberadaan preman di daerah tersebut memengaruhi beragam aktivitas, termasuk peliputan berita terkait kasus-kasus yang terjadi di wilayah tersebut.

Penggunaan preman maupun oknum aparat oleh para pejabat publik atau politisi agar penyimpangan atau skandal yang dilakukan terkait jabatannya tidak terungkap, menjadi salah satu modus yang kerap terjadi di Indonesia. Sebuah riset di AS juga menunjukkan 
bahwa ketika politisi bersikap anti-media, maka semakin besar kerentanan jurnalis mengalami tindak kekerasan (Mazzaro, 2021).

Merujuk pada kasus-kasus tersebut maka keselamatan jurnalis terkait dengan liputannya menentukan peran media untuk menjalankan fungsinya dan mendorong terwujudnya demokrasi. Dengan kata lain berbagai pengalaman jurnalis terkait dengan tindak kekerasan yang dialaminya, menjadi tantangan dalam mewujudkan peran dan fungsi media atau pers di masyarakat, serta mendorong terwujudnya demokrasi di negara ini.

\section{Penutup}

Liputan media menjadi salah satu unsur penting untuk membangun kesadaran dan partisipasi masyarakat sebagai warganegara, dan terlibat dalam isu terkait kepentingan publik. Hal ini dapat terjadi jika pers atau media melalui jurnalis sebagai aktornya dapat menjalankan perannya, khususnya terkait informasi dan kontrol sosial.

Kekerasan terhadap jurnalis masih kerap terjadi di berbagai wilayah Indonesia. Walaupun Indonesia telah memiliki kebijakan tentang perlindungan jurnalistik akan tetapi kekerasan masih terus terjadi dan tingkatnya semakin tinggi di saat situasi politik memanas. Artinya, situasi dimana rakyat berbeda pandangan dengan para pengelola negara dan membutuhkan informasi yang memadai sehingga kontrol sosial terhadap potensi terjadinya penyimpangan oleh para pejabat publik dapat dilakukan. Selain itu, dapat juga terjadi ketika terdapat perbedaan pandangan di antara kelompok masyarakat yang memicu konflik antar kelompok. Pada situasi ini maka kehadiran Jurnalis sangat diharapkan oleh sebagian pihak dan kadang dianggap ancaman oleh pihak lainnya, sehingga jurnalis memiliki resiko menjadi korban tindak kekerasan. 
Kekerasan pada Jurnalis tidak hanya merugikan Jurnalis atau medianya akan tetapi juga akan merugikan publik dan menghambat setiap sistem demokrasi yang dicita-citakan. Oleh karena itu kekerasan terhadap jurnalis seharusnya tidak diabaikan atau dijadikan urusan personal mereka. Karena ancaman yang diterima para jurnalis sehingga menghambat kerja profesionalnya akan memengaruhi terpenuhinya tidaknya hak publik, yaitu terkait informasi dan kontrol sosial pada pengelola bangsa dan negara ini baik kalangan eksekutif, legislatif maupun yudikatif. Diperlukan beragam upaya untuk meminimalkan kekerasan terhadap jurnalis dan mengembangkan media yang tidak menjadikan medianya hanya sebagai lembaga ekonomi. Oleh karena itu menjadikan pers sebagai pilar ke empat demokrasi adalah tantangan bagi media atau pers dan kita semua, untuk mewujudkan demokrasi yang dicita-citakan.

\section{Referensi}

Aliansi Jurnalis Independen. (2022). Data Kekerasan. Https://Advokasi.Aji.or.Id/. https://advokasi.aji.or.id/index/data-kekerasan/1/10.html

Brambila, J. A., \& Hughes, S. (2019). Violence against Journalists. In The International Encyclopedia of Journalism Studies (pp. 1-9). Wiley. https://doi.org/10.1002/9781118841570.iejs0248

Hardiman, F. B. (2011). Pemikiran-pemikiran yang Membentuk Dunia Modern. Erlangga.

Hardiman, F. B., \& Priotomo. (2009). Demokrasi Deliberatif. Kanisius.

Irfan, N. (2010). Teori Pengetahuan Immanuel Kant dan Implikasinya Terhadap Batas IImu. Jurnal IImiah IImu Ushuluddin, 9(1), 53-58.

https://doi.org/http://dx.doi.org/10.18592/jiu.v9i1.1409

Kant, I. (2021). The Critique of Pure Reason. diterjemahkan oleh Supriyanto Abdullah dalam “Kritik terhadap Akal Budi." Yogyakarta, Indoliterasi.

Kovach, B., \& Tom, R. (2001). The Elements of Journalism. Crown Publishers.

Kurnia, S. S. (2004). Jurnalisme Investigasi. Yayasan Pustaka Obor Indonesia.

Maryani, E. (2021). Beragam Tantangan Media Penyiaran Memenuhi Kepentingan 
Publik, Lokal, dan Komunitas dalam Demokrasi Tanpa Demos, Jakarta, LP3ES.

Mazzaro, K. (2021). Anti-Media Discourse and Violence Against Journalists: Evidence From Chávez's Venezuela. The International Journal of Press/Politics, 194016122110471. https://doi.org/10.1177/19401612211047198

McCoy, M. E. (2019). Scandal and Democracy: Media Politics in Indonesia. Cornell University Press.

Nugroho, Y., Siregar, M. F., \& Laksmi, S. (2013). Mapping Media Policy in Indonesia. Jakarta, Centre for Innovation Policy and Governance.

Reporter Without Borders. (2021). Data of press freedom ranking 2021. Rsf.Org. https://rsf.org/en/ranking_table

Safenet. (2019). Peningkatan Pelanggaran Hak-Hak Digital Jurnalis dan Media di Indonesia; Laporan SAFEnet tentang Kebebasan Pers di Indonesia. Id.Safenet.or.Id. https://id.safenet.or.id/2019/01/peningkatanpelanggaran-hak-hak-digital-jurnalis-dan-media-di-indonesia/

Shalihah, N. F. (2020). Aksi Demo Penolakan Omnibus Law UU Cipta Kerja di 9 Daerah Berlangsung Ricuh, Mana Saja? Kompas.Com. https://www.kompas.com/tren/read/2020/10/08/180500765/aksidemo-penolakan-omnibus-law-uu-cipta-kerja-di-9-daerahberlangsung?page=all\#page1

Siregar, A. E. (2019). Media, Kapitalisema, dan Demokrasi: Dalam Dinamika Politik Indonesia Kontemporer. PR2Media.

Wolfgang, J. D., Vos, T. P., Kelling, K., \& Shin, S. (2021). Political Journalism and Democracy: How Journalists Reflect Political Viewpoint Diversity in Their Reporting. Journalism Studies, 22(10), 1339-1357. https://doi.org/10.1080/1461670X.2021.1952473 


\section{Profil Penulis}

Eni Maryani adalah dosen Fakultas IImu Komunikasi, Universitas Padjadjaran. Pendidikan Magister dan Doktor diselesaikannya di Universitas Indonesia. Risetnya terfokus pada bidang Komunikasi, Media dan Gender. Eni mengajar pada Kajian Media Kritis, Industri Media, Manajemen Media Digital, Kajian TV dan Film, Teknologi Komunikasi Digital dan Masyarakat, serta Metode Penelitian Kualitatif. Karyanya telah diterbitkan diberbagai jurnal dan book chapter baik internasional maupun nasional. Saat ini Eni adalah Kepala Departemen Komunikasi dan Informasi Fikom Unpad. Beliau juga anggota dari International Association for Media and Communication Research (IAMCR), dan International Communication Association (ICA), serta Pengurus Pusat di Ikatan Sarjana Komunikasi Indonesia (ISKI). 